\title{
Clinical Characteristics of Patients with Acute Myocardial Infarction in Prof. Dr. Margono Soekarjo Regional Public Hospital, Purwokerto
}

\author{
$1^{\text {st }}$ Hana Yusri Afifah \\ Undergraduate Science of Nursing Student \\ Faculty of Health Science, Harapan Bangsa \\ University \\ Purwokerto, Indonesia \\ Email: hanayusriafifah93@gmail.com
}

\author{
$2^{\text {nd }}$ Martyarini Budi S \\ Nursing Lecturer \\ Faculty of Health Science, Harapan Bangsa \\ University \\ Purwokerto, Indonesia \\ Email: martyarini.bs@uhb.ac.id
}

\author{
$3^{\text {rd }}$ Danang Tri Yudono \\ Nursing Lecturer \\ Faculty of Health Science, Harapan Bangsa \\ University \\ Purwokerto, Indonesia \\ Email : danangtriyudono@uhb.ac.id
}

\begin{abstract}
Background: Acute myocardial infarction (IMA) is a heart disease caused by coronary arteries, and thus myocardium has lack of oxygen resulting in myocardial tissue death. In Indonesia, the prevalence of acute myocardial infarction (heart attack) has increased by $25 \%$ to $40 \%$, and the highest prevalence of non-communicable diseases is in North Kalimantan (2.2\%), Gorontalo (2.1\%), and Central Java $(1.8 \%)$. Objective: To determine the clinical characteristics of patients with acute myocardial infarction patients in Prof. Dr. Margono Soekarjo Purwokerto. Method: The research type used was a retrospective descriptive approach using the medical records of patients. The sampling technique used was a total sampling technique. 59 respondents were selected. Data analysis used was the frequency distribution and the Standard Deviation, the mean, and Min-Max. Results: It was found 59 IMA respondents, 58 people with risk at the age of $\geq \mathbf{4 0}(\mathbf{9 8 . 3} \%)$, 1 person with no risk at the age of $<40(1.7 \%), 45$ men $(76.3 \%)$, and 14 women $(23.7 \%) .39$ people $(66.1 \%)$ had a history of hypertension and 20 people $(33.9 \%)$ did not have a history of hypertension. The mean of IMT was $23.47 \pm 2.555$. The mean of pain scale was $7.02 \pm 1.603$. It was also found 35 people with anterior infarction $(59.3 \%), 18$ people with inferior infarction $(30.5 \%), 5$ people with lateral infarction $(8.5 \%)$, and 1 person with posterior infarction $(1.7 \%)$. The mean of CK-MB was 181.76 $\pm 278,323$. The Troponin mean was 3,234 \pm 4,326-10. Conclusion: Patients with acute myocardial infarction mostly were a risk at the age of $40(98.3 \%)$ and males $(76.3 \%)$. Moreover, they had a history of hypertension (66.1\%). The mean of IMT was $23.47 \pm \mathbf{2 . 5 5 5}$. The mean pain scale was 7.02 \pm 1.603. It was also found 35 people with anterior infarction (59.3\%). The mean of CK-MB was $181.76 \pm 278,323$. The Troponin mean was $3,234 \pm 4,326-10$.
\end{abstract}

Keywords: acute myocardial infarction, risk factors, clinical characteristics

\section{INTRODUCTION}

Acute myocardial infarction is a heart disease caused by a blockage in the coronary arteries. Acute blockages occur due to atherosclerosis in the walls of the coronary arteries, and thus it blocks the blood flow through the artery to the heart muscle [1]. Acute myocardial infarction is caused by several factors; modifiable and non-modifiable. Modifiable factors include age, family history, and gender, while non-modifiable factors include hypertension, diabetes mellitus, hyperlipidemia, obesity (BMI), smoking, physical inactivity, and lifestyle [2]. Signs and symptoms appearing in acute myocardial infarction are sudden chest pain lasting continuously, stabbing pain, pain radiating to shoulders and left arm, and persistent pain [3]. The results of electrocardiogram (ECG) on patients with acute myocardial infarction will show significant changes in $\mathrm{T}$-wave inversions, ST-segment elevation, and $\mathrm{Q}$ waves. The locations of myocardial infarction are in the anterior ST segment in leads VI-V6, the inferior ST-segment in leads I, II, III, and the lateral ST-segment in leads V5 and V6 [4]. The elevated levels of CK-MB (Creatinine Kinase Myocardial Band) and Troponin I indicate heart muscle. CKMB increases within 4-6 hours and peaks at 24-48 hours (Morton et al, 2011). Troponin I is a sensitive and specific indicator of optimal markers of scale muscle damage, Troponin I increases within 2 hours, peaks at 14-18 hours, and remains increased for 5 to 7 days [5].

Based on a survey conducted by the researchers on December 28, 2018, at Prof. Dr. Margono Soekarjo Hospital Purwokerto, the number of patients in 2018 from January to December 2018 was 96 patients. From 2 medical records, the clinical characteristics of patients with acute myocardial infarction were mostly males and risk at the age of $\geq 40$ years. Moreover, they had a history of hypertension and experienced moderate to severe pain scale. The ECG results also showed that myocardial infarction was in the anterior and inferior parts. Based on the results, patients experienced an increase in CK-MB and Troponin I.

Based on the explanation above, the researchers intends to find out the "Clinical Characteristics of Patients with Acute Myocardial Infarction in RSUD Prof. Dr. Margono Soekarjo Purwokerto"

\section{METHODS}

The research type used was descriptive research that is to describe data and characteristics about the population or a particular field systematically and accurately [6]. The retrospective approach was used to examine conditions that have occurred and then look back to find out the factors that can cause the conditions [7].

Data was collected in the medical record department of Prof. Dr. Margono Soekarjo Hospital Purwokerto, Indonesia from June 24 to July 24, 2019. The sampling technique used was total sampling and 59 respondents met the criteria. The 
were in an average value of $181.76 \pm 278.332$, a minimum value of 25, and a maximum of 1608 .

myocardial infarction.

The measurement applied was a Major Adverse Cardiac Event (MACE). The researchers used checklists such as age, gender, hypertension, BMI, pain scale, ECG results (anterior, inferior, posterior and lateral), and laboratory results of CK-MB and Troponin I.

The univariate analyses used were the frequency distribution and the central tendency (mean and standard deviation) and minimum or maximum value.

\section{RESULTS AND DISCUSSION}

The results can be illustrated as follows:

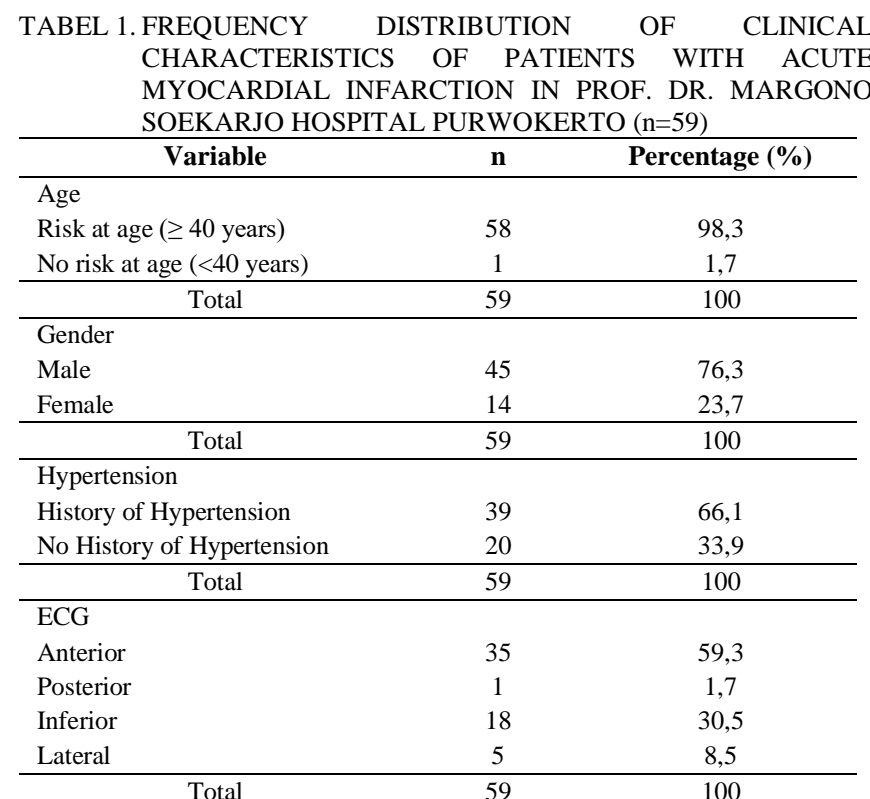

Data source: Secondary data 2018

Table 1 shows that 58 patients with acute myocardial infarction are at the age of $\geq 40$ years old $(98.3 \%)$. Besides, 45 male patients mostly experience acute myocardial infarction $(76.3 \%)$. It also shows that 39 patients with acute myocardial infarction have a history of hypertension $(66.1 \%)$. Based on ECG results, 35 patients with acute myocardial infarction experience anterior infarction (59.3\%).

TABLE 2. DISTRIBUTION OF BMI, CHEST PAIN, CK-MB ON PATIENTS WITH ACUTE MYOCARDIAL INFARCTION IN PROF. DR. MARGONO SOEKARJO HOSPITAL PURWOKERTO $(n=59)$

\begin{tabular}{lcccc}
\hline \multicolumn{1}{c}{ Variable } & Mean & SD & Min & Maks \\
\hline BMI & 23,47 & 2,555 & 18,73 & 29,74 \\
Pain Scale & 7,02 & 1,603 & 3 & 10 \\
CK-MB & 181,76 & 278,323 & 25 & 1608 \\
\hline
\end{tabular}

Data source: Secondary data, 2018

Table 2 shows that BMI values of 59 patients with acute myocardial infarction were in an average value of $23.47 \pm 2.555$, a minimum value of 18.73 , and a maximum value of 29.74. Pain scale values of 59 respondents were in an average value of $7.02 \pm 1.603$, a minimum value of 3 , and a maximum value of 10 . CK-MB values of 59 respondents
TABLE 3. DISTRIBUTION OF TROPONIN 1 ON PATIENTS WITH ACUTE MYOCARDIAL INFARCTION IN PROF. DR. MARGONO SOEKARJO HOSPITAL PURWOKERTO $(\mathrm{n}=32)$

\begin{tabular}{ccccc}
\hline Variable & Mean & SD & Min & Mak \\
\hline Troponin I & 3,234 & 4,326 & 0,01 & 10 \\
\hline
\end{tabular}

Data source: Secondary data 2018

Table 3 shows that the Troponin I laboratory results of 32 patients with acute myocardial infarction were in an average value of $3.234 \pm 4.326$, a minimum value of 0.01 , and a maximum value of 10 .

\section{DISCUSSION}

Age

The results showed that almost all respondents were in a category of risk at age ( $\geq 40$ years). This result is in line with the previous research [8] stating that of 51 respondents, 41 respondents $(80.39 \%)$ over 45 years had acute myocardial infarction. Researchers assume that infarction occurs in the elderly, and their left ventricular systolic is decreased significantly as age increases. The elderly will experience changes in vascular endothelial and thrombogenicity [9].

Gender

The results showed that most of respondents were males (45 respondents) (76.3\%). These results are in line with the previous research [10] stating that of 732 respondents, 479 respondents $(65.4 \%)$ were males. Researchers assume that gender is a risk factor, and men are prone to coronary atherosclerosis due to unhealthy lifestyles such as smoking and obesity, while women may experience it after menopause [11].

\section{History of Hypertension}

Patients with acute myocardial infarction had a history of hypertension (39 respondents) (66.1\%). These results are in line with the previous result [12] stating that of 71 respondents, 41 respondents $(57.7 \%)$ experiencing acute myocardial infarction had a history of hypertension.

Researchers assume that hypertension is a dangerous factor because it does not show any symptoms. In this case, high blood pressure causes a high-pressure gradient that must be resisted by the left ventricle when pumping blood. The continuous high pressure increases myocardial oxygen supply [13]. The mechanism of acute myocardial infarction is caused by hypertension that can increase the risks of heart. High blood pressure continuously can damage blood vessels, then slowly it causes erosion and coronary artery occlusion. Factors involved in the atherosclerosis process can cause plaque rupture resulting in thrombotic and vascular occlusion. Controlling high blood pressure can increase the oxygen supply to the heart. The blood pressure of patients with hypertension is influenced by the renin-angiotensinaldosterone system (high plasma renin activity) [13]

\section{BMI}

The results showed an average BMI of $23.47 \pm 2.555$, a minimum value of 18.73 , and a maximum value of 29.74 . The results of the previous study [14] showed that of 63 respondents, 42 people $(66.6 \%)$ were in 18.5-24.9 of BMI range, and 16 people $(25,4 \%)$ were in 25 to 29.9 of BMI 


\section{SugGestions}

range. Obesity can increase the workload of the heart and oxygen demand. Reducing oxygen supply or increasing oxygen demand can affect the balance and damage the myocardium [11].

\section{Chest Pain (Pain Scale)}

The results showed that the pain scale values were in an average value of $7.02 \pm 1.603$, a minimum value of 3 , and a maximum value of 10 . The results of the previous research [11] showed that 35 respondents $(58.3 \%)$ experienced mildmoderate pain and 25 respondents $(41.7 \%)$ had severe pain. Chest pain is a state of pain or discomfort that arises in the anterior chest above the epigastrium and under the mandible. Pain comes from the heart and it can be felt in the lower jaw [4].

\section{Electrocardiogram}

Based on the ECG results, it was found that 35 respondents $(59.3 \%)$ experiencing anterior infarction, 18 respondents $(30.5 \%)$ experiencing inferior infarction, and 1 respondent $(1.7 \%)$ experiencing posterior infarction. The previous research [15] showed patients with anterior infarction (46\%) and patients with inferior infarction (38\%). This study is following the theory of anterior infarction, in general, it relates to left ventricular hypertrophy and myocardial dysfunction which can cause heart failure, cardiomegaly, and cardiogenic shock. Inferior or posterior infarction has a greater susceptibility to bradyarrhythmia and conduction disorders [15]. Anterior wall myocardial infarction is associated with LAD (Left Anterior Descending) coronary artery, while inferior wall infarction is associated with Right Coronary Artery (RCA) disease except in patients with a left dominant system and lateral wall infarction caused by left circumflex coronary artery (LCX) disease [10].

\section{Laboratory Results: CK-MB}

Based on the CK-MB, the results were in an average value of $181.76 \pm 278.332$, a minimum value of 25 , and a maximum of 1608. In line with the previous research [16], 35 respondents $(64.83 \%)$ had CK-MB levels $\geq 24 \mathrm{u} / \mathrm{l}$. Researchers assume that an increase in CK-MB activity can lead to myocardial damage. CK-MB is for detecting heart muscle damage specifically. CK-MB enzymes in serum can increase muscle trauma. Normal levels of CK-MB do not rule out the presence of mild myocardial damage [16].

\section{Laboratory Results: Troponin I}

Based on the troponin I result, it was obtained an average value of $3.234 \pm 4.326$, a minimum value of 0.01 , and a maximum value of 10 . In line with the previous research [14] showing that the lowest value was 0.01 and the highest value was 2. Researchers assume that troponin I indicates acute myocardial infarction, and troponin I is typical of myocardial tissue and has a high sensitivity to detect the presence of small myocardial infarction undetected on electrocardiogram and CK-MB tests [13]. Troponin I as a chemical marker is preferred to use to determine myocardial injury because it is more sensitive and specific, and it needs a long time to detect acute myocardial infarction [13].
It is important to motivate nurses to improve the quality of nursing care. Complaints of pain in patients were written specifically for further examination such as CK-MB and Troponin I. From this study, it is suggested to develop and gain additional knowledge of clinical characteristics of patients with acute myocardial infarction.

\section{REFERENCES}

[1] W. P. Aspiani. Reni Yul., "Buku Ajar Asuhan Keperawatan Klien Gangguan Kardovaskular, Aplikasi NIC \& NOC.,” 2017.

[2] S. Azwar, "Metode Penelitian," pp. 9745-9747, 2016.

[3] H. Gray, K. Dawkins, I. A. Simpson, and J. Morgan, "Lecture Notes on Cardiology What people are saying - Write a review Related books," 2014

[4] Reny Yuli Aspiani, "Buku ajar: Asuhan Keperawatan Klien Gangguan Kardiovaskuler Aplikasi NIC \& NOC,” pp. 1-555, 2017.

[5] Susila and Suyanto, "Metode Penelitian Epidemiologi Bidang Kesehatan Dan Kedokteran," Pertama, pp. 1-529, 2014.

[6] B. Setyohadi, P. Arsana, A. Suryanto, S. AY, and M. Abdullah, "EIMED PAPDI Kegawatdaruratan Penyakit Dalam (Emergency in Internal Medicine)," pp. 394-400, 2012

[7] B. M. Morton, P. G., Fontaine, D., Hudak, C. M., \& Gailo, "Keperawatan Kritis : Pendekatan Asuhan Holistik Volume 2," vol. 2, 2012.

[8] C. Lolaen, S. H. Rampengan, and J. A. Pangemanan, "Gambaran Intervensi Koroner Perkutan Primer pada Pasien Infark Miokard Akut dengan Elevasi Segmen ST di RSUP Prof Dr. R. D. Kandou Manado Periode Januari -Desember 2017," e-CliniC, vol. 6, no. 2, pp. 153161, 2018.

[9] S. H. Wahyuni, "Major Adverse Cardiac Events," 2014.

[10] I. P. Farissa, Komplikasi pada Pasien Infark Miokard Akut St-Elevasi (Stemi) yang Mendapat maupun tidak Mendapat Terapi Reperfusi. 2012.

[11] N. Gusti, A. Putu, L. Santika, A. A. W. Lestari, I. W. Putu, and S. Yasa, "Hubungan kadar troponin $\mathrm{t}(\mathrm{TnT})$ dan creatinin kinasemyocardial band ( CK-MB ) pada pasien infark miokard akut ( IMA ) di Rumah Sakit Umum Pusat ( RSUP ) Sanglah Denpasar," Dir. Open Access Journals, pp. 43-48, 2018.

[12] A. Joeliantina, J. Keperawatan, P. Kemenkes, N. Dada, and I. M. Akut, "Pengaruh Teknik Relaksasi Napas Dalam Terhadap Nyeri Dada The Effect Of Deep Breath Relaxation Techniques Toward Chest Pain In Patients With Acute Myocardial Infarct," Vol. V, No. 3, Pp. 122-125, 2012

[13] Muhibbah, A. Wahid, R. Agustina, and Oskiilliandri, "PADA PASIEN RAWAT INAP RUANG TULIP Sindrom Koroner Akut merupakan," Indones. J. Heal. Sci., vol. 3, no. 1, pp. 6-12, 2019.

[14] B. Budiman, R. Sihombing, and P. Pradina, "Hubungan Dislipidemia, Hipertensi Dan Diabetes Melitus Dengan Kejadian Infark Miokard Akut," J. Kesehat. Masy. Andalas, vol. 10, no. 1, p. 32, 2017.

[15] C. Susilo, "Identifikasi Faktor Usia, Jenis Kelamin Dengan Luas Infark Miokard Pada Penyakit Jantung Koroner (Pjk) Di Ruang Iccu Rsd Dr. Soebandi Jember," Indones. J. Heal. Sci., vol. 6, no. 1, pp. 17, 2015.

[16] K. Sachdev, "Clinical Pathology and Clinical Bacteriology," Clin. Pathol. Clin. Bacteriol., vol. 22, no. 2, 1999.

[17] T. T. Saputra, I. Ketaren, A. Arundina, and T. Tejoyuwono, "Hubungan lokasi infark dengan mortalitas pada pasien infark miokard akut yang dirawat di ruang intensive cardiac care unit (iccu) rsu dokter soedarso pontianak," pp. 1-15, 2013.

[18] M. Indrawati, Ni Gusti Ayu, Mulyadi Kiling, "Pasien Sindrom Koroner Akut Di Instalasi Gawat," vol. 6, 2018.

[19] A. Astuti and M. Maulani, "Faktor Resiko Infark Miokard di Kota Jambi," J. Endur., vol. 3, no. 1, p. 82, 2018. 